\title{
PENGARUH PENGGUNAAN ASSESMENT RISIKO HIV/AIDS TERHADAP UPAYA PENATA/PERAWAT ANESTESI DALAM PELAKSANAAN PATIENT SAFETY;UNIVERSAL PRECAUTIONS
}

\author{
Yustiana Olfah $^{1}$, Ni Ketut Mendri ${ }^{2}$, Bondan Palestin ${ }^{3}$ \\ ${ }^{1,2,3}$ Jurusan Keperawatan Politeknik Kesehatan Kementerian Kesehatan Yogyakarta \\ E-mail :'yustianajogja@gmail.com, ${ }^{2}$ mendriniketut@yahoo.com, ${ }^{3}$ bondanp@ gmail.com
}

\begin{abstract}
Abstrak
Studi pendahuluan dengan wawancara pada lima penata anestesi menunjukkan bahwa belum ada alat/ instrument selain dengan pemeriksaan laboratorium yang dapat membantu petugas kesehatan khususnya penata anestesi agar mampu mengkaji pasien berisiko atau tidak terinfeksi HIV/AIDS. Dengan assesment risiko, cara ini diharapkan persiapan operasi akan lebih hati-hati dan optimal. Tujuan penelitian ini adalah untuk mengetahui pengaruh penggunaan Assesment Risiko terhadap Upaya Penata/Perawat Anestesi dalam Pelaksanaan Patient Safety;Universal Precautions di RSUD Provinsi Daerah Istimewa Yogyakarta (DIY). Jenis penelitian Quasi eksperiment dengan rancangan Pre-test Post-test Design. Sampel penelitian dilakukan secara total sampling. Rancangan ini tanpa kelompok pembanding (kontrol) dengan pertimbangan terbatasnya jumlah penata/perawat anastesi yang ada di RSUD Provinsi DIY, pengisian kuesioner dilakukan dua kali. Pertama untuk mengetahui kemampuan penata/perawat anestesi dalam deteksi risiko HIV/AIDS pasien pada saat kunjungan pra nestesi serta upaya pelaksanaan patien safety; universal precautions sebelum diberikan Assesment Risiko dan kedua sesudah diberikan pelatihan menggunakan Assesment Risiko. Pengambilan sampel dilakukan secara total sampling dengan kriteria penata/perawat anestesi yang aktif dan bekerja di kamar operasi. Data hasil pemeriksaan dianalisis secara diskriptif dan secara analitik dengan bantuan komputer menggunakan uji $\mathrm{T}$ test dengan taraf signifikan 0,05 . Uji statistik bernilai $\mathrm{p}=0,000$ artinya terdapat pengaruh penggunaan assesment risiko terhadap upaya penata/perawat anestesi dalam pelaksanaan patient safety; universal precautions di RSU Daerah Provinsi Daerah Istimewa Yogyakarta.
\end{abstract}

Kata kunci : Assesment risiko, perawat anestesi, universal precaution

\begin{abstract}
Preliminary studies by interviewing five administrators of anesthesia showed that there were no instruments / instruments other than laboratory tests that could help health workers, especially anesthetists, to be able to assess patients at risk or not infected with HIV / AIDS. With risk assessment, this method is expected to be more careful and optimal for operational preparation. The purpose of this study was to determine the effect of using Risk Assessment on the Efforts of
\end{abstract}


Anesthetists / Nurses in the Implementation of Patient Safety; Universal Precautions in Yogyakarta Special Province Hospital (DIY). The research was theQuasi-experimental with Pre-test Post-test design. The research sample was done by total sampling. This design was without comparison group (control) in consideration of the limited number of nurse anesthetist in Yogyakarta Provincial Hospital, filling out the questionnaire done twice. First, to determine the ability of the nurse anesthetist in the detection of the risk of HIV / AIDS patients at the time of the visit as well as efforts to implement pre anesthesia patient safety; universal precautions before being given a Risk Assessment and the second after trained to use Risk Assessment. Sampling was done by total sampling criteria nurse anesthetist active and working in the operating room.Statistical Test indicated the tesult was $p=0,000$ means there was an effect of using risk assessment to the nurse anesthetist in the implementation of patient safety; universal precautions in the Regional Hospital of Yogyakarta Province.

Keywords: Assessment of risk, universal precaution, nurse anesthetist

\section{PENDAHULUAN}

AIDS adalah suatu penyakit yang belum ada obatnya dan belum ada vaksin yang bisa mencegah serangan virus HIV, sehingga penyakit ini merupakan salah satu penyakit yang sangat berbahaya bagi kehidupan manusia baik sekarang maupun waktu yang datang (Mansjoer, 2001; Adhi, 2005). Selain itu AIDS juga dapat menimbulkan penderitaan, baik dari segi fisik maupun dari segi mental. Mungkin kita sering mendapat informasi melalui media cetak, elektronik, ataupun seminar, tentang betapa menderitanya seseorang yang mengidap penyakit AIDS (Adhi, 2005). Dari segi fisik, penderitaan itu mungkin, tidak terlihat secara langsung karena gejalanya baru dapat kita lihat setelah beberapa bulan. Tapi dari segi mental, orang yang mengetahui dirinya mengidap penyakit AIDS akan merasakan penderitaan batin yang berkepanjangan. Semua itu menunjukkan bahwa masalah AIDS adalah suatu masalah besar dari kehidupan (IHW, 2009).

Bersumber dari Ditjen PP dan PL Kemenkes RI yang dilaporkan pada bulan September 2014 secara kumulatif HIV dan AIDS terhitung mulai 1 April 1987 sampai dengan 30 September 2014 total HIV 150.296 dan AIDS 55.799 (Kemenkes RI, 2014).

HIV tidak ditularkan atau disebarkan melalui hubungan sosial yang biasa seperti jabatan tangan, bersentuhan, berciuman biasa, berpelukan, penggunaan peralatan makan dan minum, gigitan nyamuk, kolam renang, penggunaan kamar mandi atau WC/Jamban yang sama atau tinggal serumah bersama Orang Dengan HIV/AIDS (ODHA). ODHA yaitu pengidap HIV atau AIDS. OHIDA (Orang hidup dengan HIV atau AIDS) yakni keluarga (anak, istri, suami, ayah, ibu) atau teman-teman pengidap HIV atau AIDS. Lebih dari $80 \%$ infeksi HIV diderita oleh kelompok usia produktif terutama laki-laki, tetapi proporsi penderita HIV perempuan cenderung meningkat. Infeksi pada bayi dan anak, 90\% terjadi dari Ibu pengidap HIV. Hingga beberapa tahun, seorang pengidap HIV tidak menunjukkan gejala-gejala klinis tertular HIV, namun demikian orang tersebut dapat menularkan kepada orang lain (Kemenkes, 2011) . 
AIDS bukan penyakit, karena AIDS tidak menular. Yang menular adalah HIV yaitu virus yang menyebabkan tubuh mencapai masa AIDS. Virus ini terdapat dalam larutan darah, cairan sperma dan cairan vagina sehingga dapat menular melalui kontak darah / cairan tersebut. HIV sangat mudah mati jika di luar tubuh manusia dan sangat sensitif terhadap suhu pada $600^{\circ} \mathrm{C}$ HIV sudah mati. Perawat yang bekerja di fasilitas kesehatan sangat berisiko terpapar infeksi yang secara potensial membahayakan jiwanya (Kurniawan dan Salam, 2007).

Perawat dalam memberikan asuhan keperawatan kepada pasien akan kontak langsung dengan cairan tubuh atau darah pasien. Perawat juga dapat menjadi tempat agen infeksius dapat hidup dan berkembang biak yang kemudian menularkan infeksi dari satu pasien ke pasien yang lain. Tenaga medis yang terkena infeksi akibat kecelakaan berisiko mengidap hepatitis dan menjadi pembawa virus (Hidayat dan jong, 2005). Undangundang RI no 36 tahun 2014 tentang tenaga kesehatan menyatakan penata anestesi termasuk dalam kelompok ketekhnisian medis.

Penata anestesi adalah penata yang telah diberi pendidikan formal secara teoritis dan praktek dalam bidang anestesi dan berkompetensi untuk melakukan pelayanan dalam pelayanan anestesi.

Salah satu kegiatan kolaboratif yang dilakukan oleh penata/perawat anestesi pada saat persiapan dan evaluasi anestesi adalah kunjungan pra anestesi yang terdiri dari anamnesis terkait identitas pasien, riwayat penyakit dan obat- obatan termasuk riwayat social dan pemeriksaan fisik (Arriaga dkk., 2013; Mangku dan Agung, 2010). Pemeriksaan laboratorium HIV/AIDS belum merupakan pemeriksaan rutin sebagai bagian dari persiapan operasi sehingga tentu dengan makin tingginya kejadian HIV/AIDS kalau tidak di deteksi akan sangat membahayakan bagi tim operasi yang kemungkinan besar mengalami paparan langsung dengan cairan tubuh pasien walaupun telah dilindungi dengan pemakaian alat pelindung diri/APD (Borgmann dkk., 2015; Farnan, dan Enriquez, 2012). Sehingga untuk keamanan sangat diperlukan cara yang dapat membantu mengkaji risiko HIV/AIDS pada pasien untuk meningkatkan kehati-hatian dalam mencegah penularan dan pelaksanaan patient safety. Patient safety adalah bebas dari cidera aksidental atau menghindarkan cidera pada pasien akibat perawatan medis dan kesalahan pengobatan (Ahluwalia dan Ahluwalia, 2005).

Penatalaksanaan anestesi pada pasien HIV tidak ada kontraindikasi general anestesi, neuroaxial, maupun regional anestesi pada pasien penderita HIV, namun perlu dievaluasi dengan baik pre-operative baik dari anamnesa, pemeriksaan fisis, maupun hasil pemeriksaan penunjang untuk mengurangi angka mortalitas pasien HIVyang mendapatkan tindakan operasi dan mencegah penularan pada petugas kesehatan (Syafri dan Astuty, 2017).

Patient safety (keselamatan pasien) rumah sakit adalah suatu sistem dimana rumah sakit membuat asuhan pasien lebih aman. Hal ini termasuk: assesment risiko, identifikasi dan pengelolaan hal yang berhubungan dengan risiko pasien, pelaporan dan analisis insiden, kemampuan belajar dari insident dan tindak lanjutnya serta implementasi solusi untuk meminimalkan timbulnya risiko. Sistem ini mencegah terjadinya cedera yang di sebabkan oleh kesalahan akibat melaksanakan suatu tindakan atau tidak mengambil tindakan yang seharusnya dilakukan (DepKes RI, 2006).

Salah satu tindakan yang dapat dilakukan untuk mendukung patient safety adalah pengendalian infeksi nosokomial dengan cara melaksanakanuniversal 
precautions.Universal precautions merupakan upaya yang dilakukan dalam ranga upaya perlindungan, pencegahan dan meminimalkan infeksi silang (cross infection)antara petugas pasien akibat adanya kontak langsung dengan pasien atau cairan tubuh pasien yang terinfeksi penyakit menular (seperti HIV /AIDS). Prinsip kewaspadaan universal adalah bahwa darah dan semua jenis cairan tubuh, sektreta dan kulit yang tidak utuh serta selaput lendir penderita dianggap sebagai sumber potensial untuk penularan infeksi termasuk HIV (Widodo, 2009).

Penelitian ini berorientasi kepada penjelasan atau penemuan (invensi) untuk mengantisipasi suatu gejala/fenomena dalam hal ini kasus HIV/AIDS yang makin lama makin meningkat yang mengakibatkan meningkatnya risiko terinfeksi pada petugas kesehatan.

Berdasarkan hasil studi pendahuluan dengan wawancara pada lima perawat/penata anestesi yang ada di RSU Daerah di Yogyakarta belum ada alat/ instrument selain dengan pemeriksaan laboratorium yang dapat membantu petugas kesehatan khususnya penata/perawatanestesi agar mampu mengkaji pasien berisiko atau tidak terinfeksi HIV/AIDS. Pemeriksaan HIV/AIDS dilakukan hanya dilakukan jika terdapat tanda gejala yang nampak terlihat secara fisik seperti pasien mempergunakan tato, terdeteksi tbc, hepatitis serta diare kronis, condiloma dan pemeriksaan tersebut harus diawali dengan konseling oleh tim VCT dan akan dilakukan pemeriksaan secara sukarela. Pada dua RSUD jika pasien akan dilakukan tindakan sectiocaesarea akan dilakukan cek laboratorium terkait HIV/AIDS. Sedangkan untuk hal lain tergantung dari kejujuran pasien. Pada kenyataannya tidak semua pasien jujur dan sebagian besar pasien dan keluarga cenderung menutupi. Terdapat beberapa kasus yang diketahui pada saat akan dilakukan operasi dan bahkan setelah operasi baru petugas kesehatan mengetahui ternyata pasien tersebut mengidap HIVAIDS dan tentu hal ini sangat membahayakan.

Jika penata/perawat anestesi dapat mengkaji secara mandiridengan menggunakan assesment risiko tentangrisiko HIV/AIDS pada pasien saat kunjungan pra anestesi maka akan dapat membantu upaya pelaksanaan patient safety ; universal pre cautions agar lebih baik serta dapat meningkatkan keamanan dalam perencanaan tindakan operasi sehingga persiapan operasi akan lebih hati-hati dan mempersiapkannya dengan lebih baik.

\section{METODE PENELITIAN}

Jenis penelitian Quasi eksperiment dengan rancangan Pre test Post test Design. Sampel penelitian dilakukan secara total sampling. Dengan jumlah responden sebanyak 33 orang. Rancangan ini tanpa kelompok pembanding (kontrol) dengan pertimbangan terbatasnya jumlah penata/perawat anastesi yang ada di RSUD Provinsi DIY, pengisian kuesioner dilakukan dua kali. Pertama untuk mengetahui kemampuan penata/perawat anestesi dalam deteksi risiko HIV/AIDS pasien pada saat kunjungan pra nestesi serta upaya pelaksanaan patien safety; universal precautions sebelum diberikan Assesment Risiko dan kedua sesudah diberikan pelatihan menggunakan Assesment Risiko. Pelatihan dilaksanakan dalam 3 kali pertemuan dengan menggunakan buku saku yang dibuat oleh peneliti tentang Assessment Risiko HIV/AIDS dan Pelaksanaan Patient Safety; Universal pre cautions dengan ISBN 978-602-50873-0-1. Pengambilan sampel dilakukan secara total sampling dengan kriteria penata/perawat anestesi yang aktif dan bekerja di kamar operasi. Data hasil penelitian dianalisis secara 
diskriptif dan secara analitik dengan bantuan komputer menggunakan ujit test dengan taraf signifikan 0,05 .

\section{HASIL DAN PEMBAHASAN}

Penelitian tentang pengaruh penggunaan assesment risiko pasien HIV/AIDS terhadap upaya penata/perawat anestesi dalam pelaksanaan patient safety; universal precautions) ini dilaksanakan di RSU Daerah Provinsi Daerah Istimewa Yogyakarta (DIY) yang terdiri dari RSUD: Sleman, Wates, Kota, Bantul dan Wonosari berjumlah 33 responden perawat/penata anestesi.

\section{Karakteristik Responden}

Karakteristik responden berdasarkan Umur, Pendidikan, Jenis Kelamin, Masa Kerja, Pelatihan Patient Safety ; Universal Precautions dapat dilihat pada Tabel 1.

Berdasarkan Tabel 1 dapat dilihat bahwa distribusi usia mayoritas responden berusia 45-49 tahun sebesar 11 responden $(33,33 \%)$. Tidak ada responden yang berusia 25-29 tahun.

Mayoritas responden berjenis kelamin laki-laki sebanyak 23 orang $(69,70$ \%). Pendidikan responden mayoritas Diploma III Keperawatan sebesar 20 responden $(66,66 \%)$. Responden paling sedikit dengan pendidikan Aknes Diploma III Anastesi) sebesar 2 orang $(6,060 \%)$.
Tabel 1. Distribusi Frekuensi Karakteristik Responden Berdasarkan Umur, Pendidikan, Jenis Kelamin, Masa Kerja, Pelatihan Patient Safety;Universal Precautions

\begin{tabular}{|c|c|c|}
\hline \multirow{2}{*}{ Karakteristik } & \multicolumn{2}{|c|}{ Responden } \\
\hline & (f) & $(\%)$ \\
\hline \multicolumn{3}{|l|}{ Umur } \\
\hline a. Umur (20-25) & 2 & 6,06 \\
\hline b. Umur (25-29) & 0 & 0 \\
\hline c. Umur (30-34) & 7 & 21,21 \\
\hline d. Umur (35-39) & 5 & 15,15 \\
\hline e. Umur (45-49) & 11 & 33,33 \\
\hline f. Umur (50-54) & 5 & 15,15 \\
\hline g. Umur (55-59) & 2 & 6,06 \\
\hline h. Umur (60-64) & 1 & 3,03 \\
\hline Jumlah & 33 & $100 \%$ \\
\hline \multicolumn{3}{|l|}{ Jenis Kelamin } \\
\hline a. Laki-laki & 23 & 69,70 \\
\hline b. Perempuan & 10 & 30,30 \\
\hline Jumlah & 33 & $100 \%$ \\
\hline
\end{tabular}

\begin{tabular}{|c|c|c|}
\hline a. Diploma III Kep & 20 & 66,66 \\
\hline b. DiplomaIV Kep & 8 & 24,24 \\
\hline c. Aknes & 2 & 6,060 \\
\hline d. Sarjana Kep & 3 & 9,10 \\
\hline Jumlah & 33 & $100 \%$ \\
\hline \multicolumn{3}{|l|}{ Masa Kerja } \\
\hline a. Kurang 5 tahun & 10 & 30,30 \\
\hline b. 5-10 tahun & 13 & 39,39 \\
\hline c. 11-15 tahun & 3 & 9,09 \\
\hline d. 16-20 tahun & 5 & 15,15 \\
\hline e. 21-25 tahun & 1 & 3,03 \\
\hline f. Lebih 25 tahun & 1 & 3,03 \\
\hline Jumlah & 33 & $100 \%$ \\
\hline
\end{tabular}

\begin{tabular}{|c|c|c|}
\hline Pelatina & & \\
\hline a. YA & 8 & 24,24 \\
\hline b. Tidak & 25 & 75,76 \\
\hline Jumlah & 33 & $100 \%$ \\
\hline
\end{tabular}


Tabel 2. Nilai Kemampuan Penggunaan Asesment Risiko dan Pelaksanaan Patient Safety ; Universal Precautions Sebelum dan Sesudah

\begin{tabular}{|c|c|c|c|c|c|c|}
\hline \multirow[t]{2}{*}{ No. Resp } & \multicolumn{3}{|c|}{ Penggunaan Assesment Risiko } & \multicolumn{3}{|c|}{ Pelaksaanaan Universal Precautions } \\
\hline & Sebelum & Sesudah & Selisih & Sebelum & Sesudah & Selisih \\
\hline 1 & 34 & 36 & 2 & 68 & 73 & 5 \\
\hline 2 & 32 & 35 & 3 & 81 & 83 & 2 \\
\hline 3 & 32 & 35 & 3 & 78 & 83 & 5 \\
\hline 4 & 33 & 36 & 3 & 55 & 73 & 18 \\
\hline 5 & 32 & 35 & 3 & 78 & 80 & 2 \\
\hline 6 & 33 & 35 & 2 & 78 & 83 & 5 \\
\hline 7 & 33 & 35 & 2 & 75 & 79 & 4 \\
\hline 8 & 33 & 35 & 2 & 73 & 80 & 7 \\
\hline 9 & 33 & 36 & 3 & 75 & 78 & 3 \\
\hline 10 & 33 & 34 & 1 & 64 & 66 & 2 \\
\hline 11 & 25 & 32 & 7 & 75 & 77 & 2 \\
\hline 12 & 32 & 36 & 4 & 76 & 78 & 2 \\
\hline 13 & 27 & 34 & 7 & 67 & 75 & 8 \\
\hline 14 & 31 & 28 & -3 & 75 & 78 & 3 \\
\hline 15 & 25 & 32 & 7 & 68 & 80 & 12 \\
\hline 16 & 30 & 34 & 4 & 72 & 71 & -1 \\
\hline 17 & 34 & 36 & 2 & 60 & 60 & 0 \\
\hline 18 & 32 & 33 & 1 & 71 & 73 & 2 \\
\hline 19 & 34 & 34 & 0 & 71 & 77 & 6 \\
\hline 20 & 31 & 35 & 4 & 72 & 77 & 5 \\
\hline 21 & 32 & 35 & 3 & 74 & 73 & -1 \\
\hline 22 & 30 & 36 & 6 & 72 & 80 & 8 \\
\hline 23 & 35 & 35 & 0 & 71 & 75 & 4 \\
\hline 24 & 32 & 34 & 2 & 75 & 80 & 5 \\
\hline 25 & 32 & 34 & 2 & 69 & 73 & 4 \\
\hline 26 & 33 & 34 & 1 & 73 & 76 & 3 \\
\hline 27 & 36 & 33 & -3 & 75 & 83 & 8 \\
\hline 28 & 33 & 35 & 2 & 78 & 80 & 2 \\
\hline 29 & 35 & 35 & 0 & 78 & 83 & 5 \\
\hline 30 & 34 & 36 & 2 & 69 & 70 & 1 \\
\hline 31 & 26 & 36 & 10 & 69 & 78 & 9 \\
\hline 32 & 34 & 36 & 2 & 63 & 78 & 15 \\
\hline 33 & 34 & 35 & 1 & 68 & 83 & 15 \\
\hline
\end{tabular}

Berdasarkan Tabel 1, masa kerja responden mayoritas memiliki masa kerja 5-10 tahun sebesar 13 orang $(39,39 \%)$, sedangkan responden paling sedikit memiliki masa kerja 21-25 tahun sebanyak 1 orang $(3,03 \%)$ sama halnya dengan responden dengan masa kerja lebih dari 25 tahun. Mayoritas responden belum mengikuti pelatihan.

Berdasarkan Tabel 2 nilai kemampuan penggunaan asesment risiko sesudah diberi pelatihan dibandingkan dengan sebelum diberikan pelatihan memiliki selisih kenaikan paling besar bernilai 10, paling rendah memiliki selisih -3 (terdapat penurunan nilai dibanding sebelum dilakukan pelatihan) sebanyak 2 responden, dan 3 responden tidak terdapat perbedaan selisih sebelum dan sesudah dilakukan pelatihan penggunaan assesment risiko.

Pelaksanaan patient safety; universal precautions sesudah diberi pelatihan dibandingkan dengan sebelum diberikan pelatihan memiliki selisih paling besar bernilai 18 sebanyak 1 responden, paling rendah memiliki selisih -1 (terdapat penurunan nilai dibandingkan sebelum diberi pelatihan) sebanyak 2 responden, dan 1 responden tidak terdapat perbedaan selisih sebelum dan sesudah diberi 
pelatihan dalam pelaksanaan patient safety ;universal precautions.

Tabel 3. Nilai Minimum dan Maksimum Penggunaan Assesment Risiko dan Upaya

Pelaksanaan Patient Safety; Universal Precautions

\begin{tabular}{ccc}
\hline Variabel & Min & Max \\
\hline Pre Penggunaan Asesment & 25,0 & 36,0 \\
& 0 & 0 \\
Post Penggunaan Assement & 28,0 & 36,0 \\
& 0 & 0 \\
Pre Universal Precautions & 55,0 & 81,0 \\
& 0 & 0 \\
Post Universal Precautions & 60,0 & 83,0 \\
& 0 & 0 \\
\hline
\end{tabular}

Sebelum diberikan intervensi, kemampuan responden dalam menggunakan assesment risiko memiliki nilai minimum 25 dan nilai maksimum 36 . Setelah dilakukan intervensi, kemampuan responden dalam menggunakan assesment risiko memiliki nilai minimum 28 dan nilai maksimum 36. Pada pelaksanaan patient safety; universal precaution sebelum diberikan intervensi memiliki nilai minimum 55 dan nilai maksimum 81 . Setelah diberikan intervensi memiliki nilai minimum 60 dan nilai maksimum 83.

Tabel 4. Selisih Mean, Standard Deviasi dan Standard Error Penggunaan Assesment Risiko dan Pelaksanaan Universal Precautions

\begin{tabular}{ccccc}
\hline Variabel & $\boldsymbol{N}$ & Mean & Standart Deviasi & Standart Error \\
\hline Selisih Penggunaan Asesment & 33 & 2,5758 & 2,66962 & 0,46472 \\
Selisih Universal Precautions & 33 & 5,1515 & 4,52853 & 0,78832 \\
\hline
\end{tabular}

Tabel 5. Hasil Uji Statistik Penggunaan Assesment Risiko dan Pelaksanaan Patient Safety; Universal Precautions

\begin{tabular}{lccc}
\hline \multicolumn{1}{c}{ Variabel } & Mean \pm SD & t & $\begin{array}{c}\text { Sig. } \\
\text { (2-tailed })^{*}\end{array}$ \\
& & & \\
Penggunaan AssesmentRisiko & $2,67 \pm 2,67$ & 5,543 & 0 \\
Pelaksanaan Universal Precaution & $4,53 \pm 4,53$ & 6,535 & 0 \\
\hline$*) \operatorname{sig} \alpha<0.05$ & & &
\end{tabular}

Hasil uji statistik didapatkan hasil selisih penggunaan assesment risiko memiliki selisih mean sebesar 2,5758, standard deviasi sebesar 2,66962 dan standard error sebesar 0,46472. Pelaksanaan patient safety; universal precautions memiliki selisih mean sebesar 5,1515 , standart deviasi sebesar 4,52853 dan standart error sebesar 0,78832 .

\section{Hasil Uji Statistik Penggunaan Assesment Risiko dan Pelaksanaan Patient Safety; Universal Precautions}

Berdasarkan hasil uji statistik penggunaan assessment risiko dan pelaksanaan patient safety; universal pre caution, didapatkan nilai sig 0,000 $(<0,05)$ yang berarti ada pengaruh penggunaan assesment risiko HIV/AIDS terhadap upaya penata/perawat anastesi dalam pelaksanaan patient safety ; universal pre caution

Karakteristik responden pada penelitian ini mayoritas responden berpendidikan Diploma III sebesar 20 responden $(66,66 \%)$ dan responden paling sedikit dengan pendidikan Aknes sebesar 2 orang $(6,060 \%)$. Notoatmodjo (2010) menyebutkan bahwa pengetahuan yang dimiliki seseorang dipengaruhi oleh berbagai hal, yaitu pendidikan, sumber informasi dan usia (umur). Tingkat pendidikan mempengaruhi tingkat pengetahuan seseorang karena 
diasumsikan bahwa tingkat pendidikan akan membantu orang tersebut untuk lebih mudah menangkap dan memahami suatu informasi. Semakin tinggi pendidikan seseorang maka tingkat pemahaman juga meningkat serta tepat dalam pengambilan sikap.

Distribusi usia mayoritas responden berusia 45-49 tahun sebesar 11 responden $(33,33 \%)$. Tidak ada responden yang berusia 25-29 tahun. Mayoritas responden berjenis kelamin laki-laki sebanyak 23 orang $(69,70 \%)$. Menurut Notoatmodjo (2003), faktor umur/ usia juga dapat mempengaruhi pengetahuan seseorang. Umur lebih muda mempunyai daya ingat lebih kuat dibandingkan dengan orang yang lebih tua. Di samping itu, kemampuan untuk menyerap pengetahuan baru lebih mudah dilakukan pada umur yang lebih muda karena otak berfungsi maksimal pada umur muda.

Masa kerja responden mayoritas memiliki masa kerja 5-10 tahun sebesar 13 orang $(39,39 \%)$, sedangkan responden paling sedikit memiliki masa kerja 21-25 tahun sebanyak 1 orang $(3,03 \%)$ sama halnya dengan responden dengan masa kerja lebih dari 25 tahun. Mayoritas responden tidak mengikuti pelatihan Patient Safety ; Universal Precautions sebanyak 25 responden (75,76\%). Notoatmodjo (2010) mengungkapkan selain tingkat pendidikan, tingkat pengetahuan sesorang juga dipengaruhi oleh sumber informasi, baik yang berasal dari media massa, petugas kesehatan, pengalaman, maupun lingkungan. Pengetahuan atau kognitif merupakan domain terpenting bagi terbentuknya tindakan seseorang. Pengetahuan diperlukan sebagai dorongan psikis dalam menumbuhkan sikap dan perilaku setiap hari, sehingga dapat dikatakan bahwa pengetahuan merupakan stimulasi terhadap tindakan seseorang. Perilaku yang didasari dengan pengetahuan akan lebih langgeng daripada perilaku yang tidak didasari oleh pengetahuan.

Pada Tabel 2 tentang nilai kemampuan sebelum dan sesudah serta selisih nilai kemampuan, Tabel 3 tentang nilai minimum dan maximum penggunaan assessment risiko dan upaya pelaksanaan patient safety terlihat nilai rata-rata dan standar deviasi penggunaan assessment risiko dan pelaksanaan universal precaution sebelum dan sesudah intervensi didapatkan perubahan sebelum dan sesudah intervensi baik pada aspek penggunaan assessment risiko maupun pelaksanaan patient safety; universal precautions. Secara keseluruhan sebagian besar mengalami peningkatan. Berdasarkan proses adopsi perilaku, Notoatmodjo (2007) menyatakan bahwa dari pengalaman dan penelitian terbukti bahwa perilaku yang didasari oleh pengetahuan akan lebih langgeng daripada perilaku yang tidak didasari pengetahuan. Menurut Kholid (2012), media pembelajaran dapat mengatasi keterbatasan pengalaman yang dimiliki oleh para audience. Pengalaman tiap audience berbeda-beda, tergantung dari faktor- faktor yang menentukan kekayaan pengalaman. Suatu media dapat dijadikan sebagai miniatur, model, maupun bentuk gambar- gambar yang disajikan secara audiovisualdan audial dalam mengatasi keterbatasan pengalaman audience untuk mengetahui secara nyata objek yang akan diperkenalkan. Selain itu, media berfungsi memungkinkan adanya interaksi langsung antara audience dengan lingkungannya, menghasilkan keseragaman pengamatan, membangkitkan keinginanan minat baru, membangkitkan motivasi untuk belajar, memberikan pengalaman yang integral/menyeluruh dari konkret sampai abstrak, serta membantu menanamkan konsep dasar yang benar, konkret, dan realistis (Kholid ,2012).

Pada Tabel 4 dapat dilihat selisih mean penggunaan assessment 2,5758 
dengan standart deviasi 2,66962 menunjukan keragaman kemampuan responden cukup homogen sedangkan untuk selisih mean 5,1515 universal precautions dengan standart deviasi 4,52853 menunjukan keragaman kemampuan responden lebih variatif dibandingkan dengan penggunaan assessment. Sedangkan standart error menunjukan angka yang kecil yaitu 0,46472 untuk penggunaan assessment dan 0,78832 untuk universal precautions sehingga responden dalam penelitian ini representative.

Kemampuan penata/perawat anestesi mendeteksi risiko HIV/AIDS pada pasien serta upaya pelaksanaan patient safety; universal precautions sebelum diberi pelatihan penggunaan assesment risiko di RSU Daerah Provinsi Daerah Istimewa Yogyakarta (DIY).

Sebelum diberi pelatihan penggunaan assesment risiko, didapatkan hasil bahwa skor atau nilai tertinggi dari 33 responden adalah responden dengan total skor 36 dan paling rendah dengan skor 25. Sedangkan pelaksanaan patient safety ; universal precaution sebelum diberi pelatihan didapatkan hasil bahwa skor atau nilai tertinggi dari 33 responden adalah responden dengan total skor 81 dan paling rendah dengan skor 55 .

Kholid (2012) menyebutkan bahwa berdasarkan teori SOR (stimulusorganisme- respon) yang dikemukakan oleh Skinner, perilaku manusia dapat dikelompokkan menjadi 2, yaitu: 1) Perilaku tertutup (Covert Behavior) merupakan perilaku yang terjadi bila respon terhadap stimulus tersebut masih belum dapat diamati oleh orang lain (dari luar) secara jelas; 2) Perilaku terbuka (Overt Behavior) merupakan perilaku yang terjadi jika respons terhadap stimulus tersebut sudah berupa tindakan atau praktik ini dapat diamati oleh orang lain dari luar atau observable behavior.
Menurut Roger dalam Kholid (2012) mengungkapkan bahwa sebelum orang mengadopsi perilaku baru (berperilaku baru), di dalam diri orang tersebut terjadi proses yang berurutan, yaitu: 1) Awareness, yaitu proses dimana seseorang menyadari dalam arti mengetahui stimulus (objek) terlebih dahulu; 2) Interest, yaitu proses dimana orang mulai tertarik kepada stimulus; 3) Evaluation, yaitu seseorang mulai menimbang-nimbang baik dan tidaknya stimulus tersebut bagi dirinya; 4) Trial, yaitu proses disaat orang mulai mencoba perilaku baru; dan 5) Adoption, yaitu proses dimana orang tersebut telah berperilaku baru sesuai dengan pengetahuan, kesadaran dan sikapnya terhadap stimulus.

Kemampuan penata anestesi mendeteksi risiko HIV/AIDS pada pasien saat kunjungan pra anestesi serta upaya pelaksanaan patient safety; universal precautions sesudah diberi pelatihan penggunaan assesment risiko di RSU Daerah Provinsi Daerah Istimewa Yogyakarta (DIY).

Berdasarkan hasil penelitian, nilai kemampuan penggunaan asesment risiko sesudah diberi pelatihan dibandingkan dengan sebelum diberikan pelatihan memiliki selisih kenaikan paling besar bernilai 10 , paling rendah memiliki selisih -3 (terdapat penurunan nilai dibanding sebelum dilakukan pelatihan) sebanyak 2 responden, dan 3 responden tidak terdapat perbedaan selisih sebelum dan sesudah dilakukan assesment risiko.

Pelaksanaan patient safety; universal precautions setelah diberi pelatihan dibandingkan dengan sebelum diberikan pelatihan memiliki selisih paling besar bernilai 18 sebanyak 1 responden, paling rendah memiliki selisih -1 (terdapat penurunan nilai dibandingkan sebelum diberi pelatihan) sebanyak 2 responden, dan 1 responden tidak terdapat perbedaan selisih sebelum dan sesudah diberi 
pelatihan dalam pelaksanaan patient safety ;universal precautions.

Menurut Slameto (2003) terdapat berbagai faktor internal dan faktor external yang mempengaruhi hasil belajar seseorang. Faktor internal adalah jasmani dan psikologis sedangkan faktor external adalah keluarga, masyarakat dan sekolah dalam hal ini dapat diartikan sebagai institusi tempat bekerja sekaligus akan menjadi tempat belajar. Sedangkan menurut Syah (2011) faktor utama yang mempengaruhi hasil belajar seseorang adalah Faktor internal yakni keadaan/kondisi jasmani dan rohani peserta, faktor eksternal (faktor dari luar ), yakni kondisi lingkungan di sekitar peserta misalnya faktor lingkungan serta faktor pendekatan belajar, yakni jenis upaya belajar yang meliputi strategi dan metode yang digunakan untuk melakukan kegiatan mempelajari materi-materi. Pada penelitian ini berfokus pada penggunaan assessment risiko yang di tuliskan dalam bentuk buku saku yang merupakan salah satu faktor yang mempengaruhi hasil belajar seseorang yaitu fator pendekatan belajar dalam hal ini terkait strategi dan metode. Sedangkan faktor internal dan external tidak merupakan faktor yang diteliti.

\section{Pengaruh penggunaan assessment} risiko.

Berdasarkan hasil penelitian didapatkan hasil terdapat pengaruh penggunaan assesment risiko terhadap upaya penata/perawat anestesi dalam pelaksanaan patient safety; universal precautions di RSU Daerah Provinsi Daerah Istimewa Yogyakarta dengan nilai 0,000 .

Dalam penelitian Benawa (2010) tentang peran media komunikasi dalam pembentukan karakter intelektual di dunia pendidikan menyebutkan hubungan kerucut Edgar Dale (cone of experience). Edgar Dale memandang bahwa nilai media pembelajaran diklasifikasikan berdasarkan nilai pengalaman. Menurutnya, pengalaman itu mempunyai dua belas (12) tingkatan. Tingkatan yang paling tinggi adalah pengalaman yang paling konkret. Sedangkan yang paling rendah adalah yang paling abstrak, diantaranya : 1) Direct Purposeful Experiences, yaitu: Pengalaman yang diperoleh dari kontak langsung denganlingkungan, obyek, binatang, manusia, dan sebagainya, dengan cara perbuatan langsung; 2) Contrived Experiences, yaitu : Pengalaman yang diperoleh dari kontak melalui model, benda tiruan, atau simulasi; 3 ) Dramatized Experiences, yaitu : Pengalaman yang diperoleh melalui permainan, sandiwara boneka, permainan peran, drama soial; 4) Demonstration : Pengalaman yang diperoleh dari pertunjukan; 5) Study Trips, yaitu : Pengalaman yang diperoleh melalui karya wisata; 6) Exhibition, yaitu : Pengalaman yang diperoleh melalui pameran; 7) Educational Television, yaitu: Pengalaman yang diperoleh melalui televisi pendidikan, 8) Motion Pictures, yaitu : Pengalaman yang diperoleh melalui gambar, film hidup, bioskop; 9) Still Pictures, yaitu : Pengalaman yang diperoleh melalui gambar mati, slide, fotografi; 10) Radio and Recording, yaitu: Pengalaman yang diperoleh melalui siaran radio atau rekaman suara; 11) Visual Symbol, yaitu : Pengalaman yang diperoleh melalui simbol yang dapat dilihat seperti grafik, bagan, diagram; 12) Verbal Symbol, yaitu : Pengalaman yang diperoleh melalui penuturan kata-kata.

Media dalam hal ini dalam bentuk buku saku merupakan alat atau sarana yang digunakan untuk menyampaikan pesan dari komunikator yaitu peneliti kepada khalayak yaitu perawat/penata anastesi. Beberapa pakar psikologi menyatakan bahwa dalam komunikasi, yang paling dominan bekerja adalah pancaindra manusia, yaitu mata dan 
telinga. Media sebagai alat komunikasi yang bertujuan untuk mempengaruhi orang lain. Pengaruh adalah perbedaan antara apa yang dipikirkan, dirasakan, dan dilakukan oleh penerima sebelum dan sesudah menerima pesan. Pengaruh juga merupakan indikator dalam komunikasi yang sangat penting untuk mengetahui berhasil atau tidaknya komunikasi yang kita inginkan. Pengaruh bisa terjadi dalam bentuk perubahan pengetahuan (knowledge), sikap (attitude), dan perilaku (behavior) (Cangara, 2012; Wichaksana, 2002).

\section{KESIMPULAN}

Berdasarkan hasil penelitian didapatkan hasil

1. Sebelum diberikan pelatihan penggunaan assessment risiko didapatkan hasil nilai rata rata dan standart deviasi 31,97 \pm 2,71 dan pelaksanaan patient safety; universal precautions $71,69 \pm 5,63$
2. Sesudah diberikan pelatihan penggunaan assessment risiko didapatkan hasil nilai rata rata dan standart deviasi $34,55 \quad \pm 1,63$ dan pelaksanaan patient safety; universal precautions $76,85 \pm 5,19$

3. Terdapat pengaruh penggunaan assesment risiko terhadap upaya penata/perawat anestesi dalam pelaksanaan patient safety; universal precautions di RSU Daerah Provinsi Daerah Istimewa Yogyakarta dengan nilai 0,000 .

\section{SARAN}

Untuk perawat/penata anastesi diharapkan dapat menerapkan assesment risiko HIV/AIDS dan tetap meningkatkan pelaksanaan patient safety; universal precautions. Sedangkan untuk rumah sakit dapat mempertimbangkan untuk menjadikan pemeriksaan HIV/AIDS sebagai salah satu persyaratan sebelum dilakukan operasi terutama untuk kasus yang berisiko.

\section{DAFTAR PUSTAKA}

Adhi, J. (2005). Ilmu Penyakit Kulit dan Kelamin. FKUI, Jakarta.

Ahluwalia, V.K., \& Ahluwalia, M., (2005). HIV/AIDS Transmission, Prevention and Alternatives Therapies. Lotus Press, India.

Arikunto, S. (2006). Prosedur Penelitian Suatu Pendekatan Praktek Edisi Refisi VI. PT Asdi Mahasatya, Jakarta.

Arriaga, A.F., Bader, A.M., Wong, J.M., Lipsitz, S.R., Berry, W.R., Ziewacz, J.E., Hepner, D.L., Boorman, D.J., Pozner, C.N., Smink, D.S., \& Gawande, A.A. (2013). Simulation-based trial of surgical-crisis checklists. $N$ Engl J Med; 368:246-53.

Birnbach, D.J. \& Hernandez, M. (2007). Neuraxial an-algesia For Labor in Spinal and Epidural anaesthesia, Wong CA (ed). p.257-74. Mc Graw-Hill, New York.

Borgmann, H., Helbig, S., Reiter, M. a., Hüsch, T., Schilling, D., Tsaur, I., \& Haferkamp, A. (2015). Utilization of surgical safety checklists by urological surgeons in Germany: a nationwide prospective survey. Patient Safety in Surgery, 9(1), 37. doi:10.1186/s13037-015-0082-5.

Cangara, H. (2012). Pengantar Ilmu Komunikasi. PT Raja Grafindo Persada, Jakarta.

Dale, E. (1969). Audio Visual Methods in Teaching. Holt, Rinehart and Winston Inc. The Dryden Press, New York. 
Farnan, R., \& Enriquez, M.(2012). What Nurses Know...HIV/AIDS : The Answer You Need From The People You Trust, Demos Medical Publishing, New York.

International Labour Organization (ILO). (2013). Keselamatan dan Kesehatan Kerja Sarana untuk Produktivitas. ILO, Jakarta.

Kemenkes RI. (2006). Panduan Nasional Keselamatan Pasien Rumah Sakit (patient safety). Utamakan Keselamatan Pasien. Kementerian Kesehatan Republik Indonesia.

Kemenkes RI. (2011). Pedoman Nasional Tatalaksana Klinis Infeksi HIV dan Terapi Antiretroviral pada Orang Dewasa. Kementerian Kesehatan Republik Indonesia.

Kemenkes RI. (2014). Statistik Kasus HIV/AIDS di Indonesia. Kementerian Kesehatan Republik Indonesia.

Kholid, A. (2012). Promosi Kesehatan. Raja Grafindo Persada, Jakarta.

Mangku,G. \& Senapathti, T. (2010). Buku Ajar Anestesi Reanimasi, Cetakan Pertama, Jakarta.

Mansjoer, A. (2001). Kapita Selekta Kedokteran Jilid I. Medis Aesculapius, Jakarta.

Muhibbin, S. (2011). Psikologi Belajar. Bumi Aksara, Jakarta.

Notoatmodjo, S. (2010a). Metodologi Penelitian Kesehatan Edisi Revisi. Rineka Cipta, Jakarta.

(2010b). Promosi Kesehatan dan Ilmu Perilaku. RinekaCipta, Jakarta.

Slameto. (2003). Belajar dan Faktor-Faktor yang Mempengaruhinya. Rineka Cipta, Jakarta.

Syamsu, H R. \& De Jong Wim. (2005). Buku Ajar Ilmu Bedah, Edisi Revisi. EGC, Jakarta.

Syafri, K. A., \& Irda, A. (2017). Anestesi Pasien HIV. Nusantara Medical Science Journal 1. (2017) 28-32

Widodo, E. (2009). Praktik Wanita Pekerja Seks (WPS) Dalam Pencegahan Penyakit Infeksi Menular Seksual (IMS) Dan HIV\&AIDS Di Lokalisasi Koplak, Kabupaten Grobogan. The Indonesian Journal of Health Promotion (Jurnal Promosi Kesehatan Indonesia), 4(2), 94-102. 